\title{
20. GEOCHEMISTRY OF CARBON: DEEP SEA DRILLING PROJECT LEG 61, NAURU BASIN, NORTH PACIFIC ${ }^{1}$
}

\author{
Karl S. Schorno, Phillips Petroleum Company, Bartlesville, Oklahoma
}

\section{INTRODUCTION}

Seven quartered sections of Pliocene to Mesozoic (Cenomanian) cores from the Nauru Basin contain primarily marine organic matter admixed with detectable amounts of terrigenous organic matter. The mixture is immature with respect to organic genesis. Chemical properties of this organic matter are compared with properties of other deep-ocean cores from DSDP sites in the central Pacific.

\section{RESULTS AND DISCUSSION}

The sampling and analysis procedures used in this study were reported previously (Schorno, in press). The organic and inorganic compositional data obtained from the homogenized core, along with sub-bottom depths and chronostratigraphies, are given in Table 1 . Table 2 contains the results of the organic analyses of the bitumen fractions. The results of capillary gas chromatographic analyses of the saturate fraction are reported in Table 2 as the ratios of marine to terrigenous $n$-alkanes, $S\left(S=\left(n-\mathrm{C}_{21}+n-\mathrm{C}_{22}\right) /\left(n-\mathrm{C}_{28}+n-\mathrm{C}_{29}\right)\right)$, the ratios of pristane to phytane, pristane to $n-\mathrm{C}_{17}$, and phytane to $n-\mathrm{C}_{18}$, and OEP (the ratio of odd to even $n$-alkanes between $n-C_{23}$ and $n-C_{35}$ ). The following report is divided into a discussion of the origin of the organic matter in these sediments, its state of maturation, and the oxidizing/reducing state of the depositional environment. A brief comparison of these sediments with similar sediments from DSDP sites in the North Pacific also is made.

\section{ORGANIC SOURCE}

The organic matter within the cores taken from Units I, II, and III appears to be derived primarily from marine rather than terrestrial organisms. This assignment of source is based on the occurrence of primarily marine carbonates within these units, a ratio of marine to terrigenous $n$-alkanes indicative of a marine source, a normal distribution of $n$-alkanes (neither an odd nor an even preference) in the $n-\mathrm{C}_{23}$ to $n-\mathrm{C}_{35}$ carbon-number range, and the large amount of organic nitrogen in these sediments.

\section{Marine Carbonates}

The carbonate-carbon of the first five cores listed in Table 1, in the interval from the Pliocene at 24 meters to the upper Eocene at $\mathbf{3 3 6}$ meters, appears to have been

\footnotetext{
${ }^{1}$ Initial Reports of the Deep Sea Drilling Project, Volume 61.
}

derived from marine organisms. With the exception of Core 462-3, Section 4, the marine carbonate content in these two units amounts to over $9 \%$ of the total weight of the sediment, that is, more than $80 \%$ as calcium carbonate. Core 462-3, Section 4, was probably deposited below the CCD (Site Summary, this volume). The carbonate content is still relatively high in the Lower Maestrichtian and Campanian cores from Unit III, averaging $44 \%$, and then drops off sharply in the Cenomanian to $1.4 \%$.

\section{Marine versus Terrigenous $\boldsymbol{n}$-Alkanes}

The ratio of marine to terrigenous $n$-alkanes, as given by $S=\left(n-\mathrm{C}_{21}+n-\mathrm{C}_{22}\right) /\left(n-\mathrm{C}_{28}+n-\mathrm{C}_{29}\right)$ (Philippi, 1974) ranges from 1.8 near the top of Unit $I$ to 0.5 for Core 462-59, Section 1, in the Cenomanian at 650 meters. Philippi has demonstrated that $S$ is typically less than 0.8 for terrigenous crude oils, and greater than 1.5 for marine crude oils. Two of the seven cores studied show $S$ values greater than 1 . The $S$ values for four of these cores fall between these two ranges. If one assumes that $S$ values derived from crude oils can be used for bitumens, one can speculate that the bitumens for which $S$ is 1 to 1.5 contain a $50 / 50$ mixture of marine and terrigenous organic matter. The deepest sample studied has an $S$ value of 0.5 . In this case, the terrigenous input appears to have been high. However, as will be noted later, the values for the pristane-to-phytane ratio and $\overline{\mathrm{OEP}}$ are not in agreement with this interpretation. The assumption that $S$ is a quantitative indicator of the amount of either terrestrial or marine input into the environment is probably erroneous. As noted by Cornford (1978), a minor input of plant cuticle can produce a major change in the amount of $\mathrm{C}_{28}$ and $\mathrm{C}_{29}$ $n$-alkanes, whereas a major algal input is necessary to give only a slight change in the $\mathrm{C}_{21}$ and $\mathrm{C}_{22} n$-alkane content. Therefore, an $S$ value near 1 is probably still indicative of a major marine input into the total organic pool. In addition to the ratio of marine-to-terrigenous $n$-alkanes, other parameters support the mostly marine assignment, at least for Units I and II and most of Unit III. These are the odd/even ratio of $n$-alkanes, as given by $\overline{\mathrm{OEP}}<1.3 \overline{(\mathrm{OEP}}$ is a mathematical expression of the changes in the odd-to-even distribution of $n$-alkanes between $n-\mathrm{C}_{23}$ and $n-\mathrm{C}_{35}$, as given by Scalan and Smith, 1976) and the high ratio of organic nitrogen to organic carbon in these sediments.

\section{Odd-Even Predominance ( $\overline{\mathbf{O E P}})$}

For five of the eight sediments given in Table $2 \overline{\mathrm{OEP}}$ calculated for $n$-alkanes between $n-\mathrm{C}_{23}$ and $n-\mathrm{C}_{35}$ is less 
Table 1. Geochemical data on homogenized cores from Leg 61, Hole 462.

\begin{tabular}{|c|c|c|c|c|c|c|c|c|}
\hline \multirow[b]{2}{*}{$\begin{array}{c}\text { Sample } \\
\text { (interval in cm) }\end{array}$} & \multirow[b]{2}{*}{ Chronostratigraphy } & \multirow[b]{2}{*}{$\begin{array}{l}\text { Sub-bottom } \\
\text { Depth } \\
\text { (m) }\end{array}$} & \multicolumn{2}{|c|}{ Carbonate } & \multirow[b]{2}{*}{$\begin{array}{l}\text { Organic } \\
\text { Carbon } \\
\text { (wt. \%) }\end{array}$} & \multicolumn{2}{|c|}{ Kjeldahl N (ppm) } & \multirow[b]{2}{*}{$\begin{array}{c}\text { Atomic } \\
\text { Ratio } \\
\text { OC/ON }\end{array}$} \\
\hline & & & $\begin{array}{l}\text { Carbon } \\
\text { (wt. \%) }\end{array}$ & $\begin{array}{c}\text { as } \\
\mathrm{CaCO}_{3} \\
\text { (wt. \%) }\end{array}$ & & $\begin{array}{c}\text { Ammonium } \\
\text { Nitrogen } \\
\text { (half) }\end{array}$ & $\begin{array}{c}\text { Organic } \\
\text { Nitrogen } \\
\text { (full- } \\
\text { half) }\end{array}$ & \\
\hline \multicolumn{9}{|l|}{ Unit I } \\
\hline $462-3-4,100-125$ & Pliocene & 24.3 & 0.2 & 2 & 0.16 & 66 & 423 & 4 \\
\hline $7-5,100-125$ & $\begin{array}{l}\text { Late Miocene- } \\
\text { Pliocene }\end{array}$ & 63.6 & 11.1 & 93 & 0.07 & 37 & 96 & 9 \\
\hline $12-5,100-125$ & Middle Miocene & 112.0 & 9.7 & 80 & 0.08 & 40 & 98 & 10 \\
\hline \multicolumn{9}{|l|}{ Unit II } \\
\hline $22-5,100-125$ & Late Oligocene & 207.0 & 9.6 & 80 & 0.06 & 34 & 95 & 7 \\
\hline $36-3,100-125$ & Late Eocene & 336.8 & 9.7 & 81 & 0.07 & 33 & 92 & 9 \\
\hline \multicolumn{9}{|l|}{ Unit III } \\
\hline $49-4,100-130$ & Lower Maestrichtian & 461.0 & 4.1 & 34 & 0.19 & 41 & 125 & 18 \\
\hline $54-2,120-140$ & Campanian & 511.7 & 6.4 & 51 & 0.07 & 33 & 85 & 10 \\
\hline $59-1,120-140$ & Cenomanian & 550.5 & 1.4 & 11 & 0.04 & 34 & 103 & 5 \\
\hline
\end{tabular}

Note: Calcium carbonate determined by dividing carbonate carbon by 0.12 .

Table 2. Geochemical data on the bitumen fraction of cores from Leg 61, Hole 462.

\begin{tabular}{|c|c|c|c|c|c|c|c|c|c|c|c|}
\hline Core & Section & $\begin{array}{c}\text { Bitumen } C^{a} \\
(\mathrm{ppm})\end{array}$ & 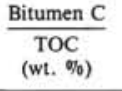 & $\begin{array}{l}\text { Saturate } \\
\text { (wt. \%) }\end{array}$ & $\begin{array}{c}\text { Aromatic } \\
\text { (wt. \%) }\end{array}$ & $\begin{array}{l}\text { Asphaltic } \\
\text { (wt. \%) }\end{array}$ & $\overline{\mathrm{OEP}}$ & $\mathrm{S}$ & $\frac{\text { Pristane }}{\text { Phytane }}$ & $\frac{\text { Pristane }}{n-C_{17}}$ & $\frac{\text { Phytane }}{n-\mathrm{C}_{18}}$ \\
\hline \multicolumn{12}{|c|}{ Unit I } \\
\hline $\begin{array}{r}3 \\
7 \\
12\end{array}$ & $\begin{array}{l}4 \\
5 \\
5\end{array}$ & $\begin{array}{r}13 \\
6 \\
13\end{array}$ & $\begin{array}{l}0.8 \\
0.9 \\
1.6\end{array}$ & $\begin{array}{c}6 \\
b \\
13\end{array}$ & $\begin{array}{l}19 \\
b \\
14\end{array}$ & $\begin{array}{c}74 \\
b \\
73\end{array}$ & $\begin{array}{l}1.4 \\
1.0^{\mathrm{d}} \\
1.2\end{array}$ & $\begin{array}{l}1.3 \\
1.8 \\
-\mathrm{c}\end{array}$ & $\begin{array}{l}0.9 \\
0.1 \\
-c\end{array}$ & $\begin{array}{l}0.2 \\
1.1 \\
-\mathrm{c}\end{array}$ & $\begin{array}{l}0.3 \\
4.9 \\
-c\end{array}$ \\
\hline \multicolumn{12}{|c|}{ Unit II } \\
\hline $\begin{array}{l}22 \\
36\end{array}$ & $\begin{array}{l}5 \\
3\end{array}$ & $\begin{array}{l}6 \\
6\end{array}$ & $\begin{array}{l}1.0 \\
0.9\end{array}$ & $\begin{array}{l}b \\
b\end{array}$ & $\begin{array}{l}b \\
b\end{array}$ & $\begin{array}{l}b \\
b\end{array}$ & $\begin{array}{l}1.2^{\mathrm{d}} \\
1.1^{\mathrm{d}}\end{array}$ & $\begin{array}{l}1.0 \\
1.7\end{array}$ & $\begin{array}{l}0.3 \\
0.4\end{array}$ & $\begin{array}{l}0.6 \\
1.0\end{array}$ & $\begin{array}{l}2.4 \\
3.0\end{array}$ \\
\hline \multicolumn{12}{|c|}{ Unit III } \\
\hline $\begin{array}{l}49 \\
54 \\
59\end{array}$ & $\begin{array}{l}4 \\
2 \\
1\end{array}$ & $\begin{array}{l}6 \\
2 \\
1\end{array}$ & $\begin{array}{l}0.3 \\
0.3 \\
0.3\end{array}$ & $\begin{array}{l}11 \\
11 \\
b\end{array}$ & $\begin{array}{l}30 \\
23 \\
\mathrm{~b}\end{array}$ & $\begin{array}{l}59 \\
66 \\
b\end{array}$ & $\begin{array}{l}1.2 \\
1.6 \\
1.4^{d}\end{array}$ & $\begin{array}{l}0.9 \\
1.1 \\
0.5\end{array}$ & $\begin{array}{l}0.6 \\
0.6 \\
0.4\end{array}$ & $\begin{array}{l}1.1 \\
0.6 \\
1.8\end{array}$ & $\begin{array}{l}1.4 \\
0.6 \\
4.7\end{array}$ \\
\hline
\end{tabular}

than 1.3. Generally, $\overline{\mathrm{OEP}}$ is either maturity-dependent, source-dependent, or both. $\overline{\mathrm{OEP}}$ is less than 1.3 for either organic matter in the catagenetic or metagenetic stage of evolution, or for organic matter derived primarily from marine organisms. In the first case, it has been well established that immature sedimentary organic matter containing only a trace of terrigenous organic matter has $\overline{\mathrm{OEP}}$ values greater than 1.3. As maturation proceeds, an evolution of $n$-alkanes with neither an odd nor even preference in the $\mathrm{C}_{23}$ to $\mathrm{C}_{25}$ range occurs, which consequently wipes out the original high $\overline{\mathrm{OEP}}$ value. In the second case, Hunt and others (Hunt, 1979) have shown that marine organisms synthesize $n$-alkanes with neither an odd nor even preference in the $\mathrm{C}_{23}$ to $\mathrm{C}_{35}$ range. Moreover, Koons et al. (1965) and Powell and McKirdy (1973) have shown that for purely carbonate sediments $\overline{\mathrm{OEP}}$ is less than 1.3 at shallow depths (low temperatures), even in Tertiary sediments. Thus, if the input of terrigenous organic matter is much less than that of marine organic matter, then $\overline{\mathrm{OEP}}$ will be near unity early in its evolutionary history as well as late; thus $\overline{\mathrm{OEP}}$ in this case is source-dependent, and not maturity-dependent, suggesting a marine source for the Nauru Basin sediments.

\section{Organic Nitrogen from Marine Organisms}

The amount of organic nitrogen in these cores is relatively high, as indicated by an atomic ratio of organic carbon $(\mathrm{OC})$ to organic nitrogen $(\mathrm{ON})$ less than 20. In general, marine organisms contain a higher percentage of organic nitrogen than continental plants. We have set a tentative cut-off value for $\mathrm{OC} / \mathrm{ON}$ of 20 as an approximate upper limit for purely marine organic matter. This value is empirically derived from a compilation of values obtained from at least 500 DSDP samples analyzed in this laboratory in the past 10 years. It is merely an estimate of marine content, and should only be used to support other source parameters. The average value for this ratio for the cores under study is 9 , with a range from 4 to 18 , well below the tentative cut-off value of 20 .

\section{MATURITY}

The sedimentary organic matter within these cores is in an early stage of maturation (the diagenetic stage as defined by Tissot and Welte, 1978a). This assignment is based on a presumably low-temperature history for these sediments, low ratios of both bitumen to TOC and 
saturates plus aromatics to total bitumen, and the predominance of phytane over $n-\mathrm{C}_{18}$.

The percentage of the bitumen-carbon portion of the TOC for marine organic matter should be greater than $5 \%$ (Philippi, 1965) for sediments in either the catagenetic or early metagenetic stages of organic maturation. The average value for the weight per cent bitumen carbon for these cores is $0.8 \%$, with a range from 0.3 to $1.6 \%$. These values are well below that expected for the stages of evolution of marine organic matter noted above.

The amount of saturates plus aromatics fraction of the total bitumen (HC) increases with a corresponding decrease in the asphaltic fraction (non-HC) with depth in these units. The ratio of non- $\mathrm{HC} / \mathrm{HC}$ never reaches that typical of source rocks of petroleum, i.e., the catagenetic stage of organic evolution. Based on published $\mathrm{HC}$ and non-HC values (Tissot and Welte, 1978b), the ratio of $\mathrm{HC} /$ non-HC for sources of petroleum is 0.91 for an average of rock types, 0.87 for shales and silts, 0.96 for calcareous shales, and 1.4 for carbonates. This ratio for Cores 462-3, Section 4, and 462-12, Section 5, are highly indicative of immature sediments (2.96 and 2.70 , respectively). The ratio decreases with depth to 1.44 and 1.94 for Cores 462-49, Section 4, and 462-54, Section 2, in Unit III. Both values are above the value expected for source rocks of petroleum, as noted above.

The third maturity parameter used in this report is the ratio of phytane to $n-\mathrm{C}_{18}$. The ratio of phytane to $n-\mathrm{C}_{18}$ is high (greater than 1), suggesting that maturation has not progressed beyond the diagenetic stage. The rate of conversion of phytol to phytane is relatively fast compared to the rate of formation of $n$-alkanes. Thus, phytane (in reducing environments) or pristane (in oxidizing environments) forms faster than the $n$-alkane $n-\mathrm{C}_{18} \quad\left(n-\mathrm{C}_{17}\right.$ for oxidizing environments); thus, the isoprenoid predominates over its associated $n$-alkane in the earliest stages of genesis (the diagenetic stage).

The hydrogen and oxygen indices (HI and OI) (Espitalié et al., 1977) generated aboard ship contradict the maturity assignment just mentioned for at least the depth interval 400 to 800 meters. In this case, the hydrogen and oxygen indices obtained from the pyrolysis of the whole-rock kerogen suggest that the organic matter in these sediments is either in a late stage of maturation (catagenesis stage), is derived from mostly terrigenous sources, or is highly oxidized, as indicated by low values for HI (less than 100) and high values of OI (greater than 50). The averages of these two values for 29 cores from Site 462 are $83 \mathrm{mg} \mathrm{HC} /$ and $887 \mathrm{mg}$ $\mathrm{CO} 2 / \mathrm{g}$ TOC. $^{2}$ The equivalent kerogen $\mathrm{H} / \mathrm{C}$ and $\mathrm{O} / \mathrm{C}$ values obtained from linear-regression analyses of Espitalie's (1977) original data $(\mathrm{H} / \mathrm{C}=0.00137 \mathrm{HI}+$ 0.589 and $\mathrm{O} / \mathrm{C}=0.00395 \mathrm{OI}+0.04$ ) are approximately 0.71 and 3.4 , respectively. In the latter case, an

\footnotetext{
2 The shipboard data were found to be invalid and will not be published elsewhere in this volume.
}

$\mathrm{O} / \mathrm{C}$ ratio of 3.4 is considered improbable. Assuming that at least the HI data are correct, the three possible cases just mentioned directly contradict the results that we present herein. A reason for this contradiction may be that assignments of organic source and maturity and of the reducing state of the depositional environment are based herein solely on data obtained from the bitumen fraction, whereas the hydrogen index is determined solely from the whole-rock kerogen, in this case possibly reworked organic matter. Because only a small marine portion of the total kerogen is necessary to produce a marine bitumen fraction, the kerogen could be primarily terrigenous, while the bitumen is marine.

\section{REDUCING ENVIRONMENT}

The data presented below indicate that the organic matter in these sediments was deposited in a reducing environment. The reducing state of the environment of deposition is indicated by a low $\overline{\mathrm{OEP}}$ value, near unity, and a ratio of pristane to phytane of less than 1 . Tissot and Welte (1978a), Hunt (1979), and this author (DSDP Legs 58, 59, and 60) have reported cases where OEP is less than 1.3 for open marine reducing environments. In Tissot and Welte's case, $\overline{\mathrm{OEP}}$ values are generally less than 0.8 , from which they infer that $n$-alkanes are generated by the reduction of fatty acids from plant waxes. In a highly reducing open marine environment, the predominance of odd-carbon-numbered acids and alcohols in the $\mathrm{C}_{25}$ to $\mathrm{C}_{35}$ range found in terrigenous source materials would be reduced to even-carbon-numbered $n$-alkanes, whereas if the organic matter were deposited in a highly oxidizing environment decarboxylation would be favored. Thus the one-carbon-less odd $n$-alkane would be generated. This hypothesis suggests a relatively high even-carbon predominance for immature sediments $(\overline{\mathrm{OEP}}<0.8)$. In our case, $\overline{\mathrm{OEP}}$ is neither high $(>1.6)$ nor low $(<0.8)$, suggesting a source of these $n$-alkanes different from immature even-carbon-numbered acids and alcohols. As noted by Tissot and Welte in this same discussion, if the environment of deposition is reducing, then the ratio of pristane to phytane should be less than 1. Basically, the same type of argument used above for the transformation of fatty acids and alcohols to $n$-alkanes holds for these isoprenoids. Because in most instances phytol is the precursor of pristane and phytane, in a reducing environment phytol is reduced primarily to phytane. In an oxidizing environment, phytol is oxidized to phytanic acid, then decarboxylated to pristene, and finally reduced to pristane. Low values for both $\overline{\mathrm{OEP}}$ and the ratio of pristane to phytane indicate that marine organic matter was deposited in a reducing environment. Some marine organisms do synthesize pristane. However, because phytane predominates, this contribution must be small. Now, if a considerable portion of the kerogen was terrigenous and was deposited in a reducing environment, one would expect to find $\overline{\mathrm{OEP}}<0.8$, as noted above. Because it is not, we favor the marine source for these kerogens. 


\section{COMPARISON OF LEG 61 ORGANIC GEOCHEMICAL DATA WITH THOSE OBTAINED FROM OTHER NORTH PACIFIC “OPEN” MARINE SEDIMENTS}

I have compiled the averaged values of 11 geochemical properties taken from DSDP cores from sites in the North Pacific and listed these values in Table 3; average values for each of the eleven sites listed in this table are also given. The Nauru Basin values compare favorably with averages for the Mariana Trough and fore-arc regions (Leg 60). The organic matter within the sediments taken during Leg 60 fits the criteria for marine organic matter deposited in a reducing environment, that is, $\overline{\mathrm{OEP}}<1.3$, pristane/phytane $<1$, OC/ON $<20$, and $S>1.0$. The Nauru Basin, compared to the Leg 60 sediments, appears to contain more terrigenous organic matter, as indicated by slightly lower $S$ values.

\section{CONCLUSIONS}

Because of a low supply of nutrients in this isolated basin, a loss of organic matter during settling to the bottom, and/or the low input of transported organic matter from other sources, the amount of organic matter that finally accumulated in the bottom sediments was low, near the average for open marine sediments $(0.1 \%$ organic carbon).

Most of the sediments deposited at this site are marine carbonates and are either autochthonous or transported to the site. These sediments could have been deposited on adjacent structural highs, as noted in the Site Summary (this volume). Our data indicate that primarily marine organic matter was deposited in either a reducing environment or an oxygen-minimum zone and has undergone some diagenetic changes (to generate pristane and phytane from phytol). The sediments then could have been redeposited by slumping or turbidity currents into the Nauru Basin. Additional alteration of the organic matter within these sediments because of the latter movement are not determinable by our measurements. The organic matter in these sediments appears to be derived primarily from marine organisms with the possible exception of the lowermost core, 462-59, Section 1. This core still contains a noticeable terrigenous imprint. The assignment of the source of the organic matter in these sediments is based heavily on the two parameters $\overline{\mathrm{OEP}}(<1.3)$ and $S(>1)$. There is a con- siderable amount of uncertainty in the assignment of source using these parameters. Also, the HI values reported in the Site Summary are in direct contradiction with the marine assignments given above. Additional research is needed to clarify these ambiguities, so that the mechanism of organic accumulation within this type of environment can be better understood.

The average values of geochemical properties for the pelagic sediments of the Nauru Basin are compared with similar properties for sites in the central Pacific. There are some similarities between the Nauru Basin sediments and similar sediments of the North Pacific. As more data are accumulated, one may be able to statistically establish an averaged parameter for the deposition of marine organic matter in deep oceanic environments.

\section{ACKNOWLEDGMENT}

I would like to thank J. Whelan (Woods Hole Oceanographic Institute), J. Louda (Florida Atlantic University), and J. Natland (Deep Sea Drilling Project) for their review of this paper.

\section{REFERENCES}

Cornford, C., 1978. Organic geochemistry of DSDP Leg 47A, Site 397 eastern North Atlantic: organic petrography and extractable hydrocarbons. In von Rad, U., Ryan, W. B. F., et al., Init. Repts. DSDP, 47, Pt. 1: Washington (U.S. Govt. Printing Office), 511522.

Espitalié, J., Laporte, J. L., Madec, M., et al., 1977. Methode rapide de caracterisation des roches meres, de leur potential petrolier et de leur degre d'evolution. Rev. Inst. Fr. Pet., 32:23-42.

Koons, C. B., Jamieson, G. W., and Ciereszko, L. S., 1965. Normal alkane distributions in marine organisms: possible significance to petroleum origin. Bull. Am. Assoc. Petrol. Geol., 49:301-316.

Philippi, G. T., 1965. On the depth, time, and mechanism of petroleum generation. Geochim. Cosmochim. Acta, 29:1021-1049. 1974. The influence of marine and terrestrial source material on the composition of petroleum. Geochim. Cosmochim. Acta, 39:947-966.

Powell, T. G. and McKirdy, D. M., 1973. The effects of source material, rock type and diagenesis on the $n$-alkane content of sediments. Geochim. Cosmochim. Acta, 37:623-633.

Scalan, R. S., and Smith, J. E., 1976. An improved measure of the odd-even predominance on the normal alkanes of sediment extracts and petroleum. Geochim. Cosmochim. Acta, 34:611-620.

Schorno, K. S., in press. Geochemistry of Carbon: International Phase of Ocean Drilling Project Leg 60. In Hussong, D., Uyeda, S., et al., Init. Repts. DSDP, 60: Washington (U.S. Govt. Printing Office).

Tissot, B. P., and Welte, D. H., 1978a. Petroleum Formation and Occurrence: New York (Springer-Verlag), pp. 69-70.

1978b. Petroleum Formation and Occurrence: New York (Springer-Verlag), pp. 95-96. 
Table 3. A compilation of average values of 11 organic chemical properties of cores from DSDP Legs 56, 58, 59, 60, and 61 in the North Pacific.

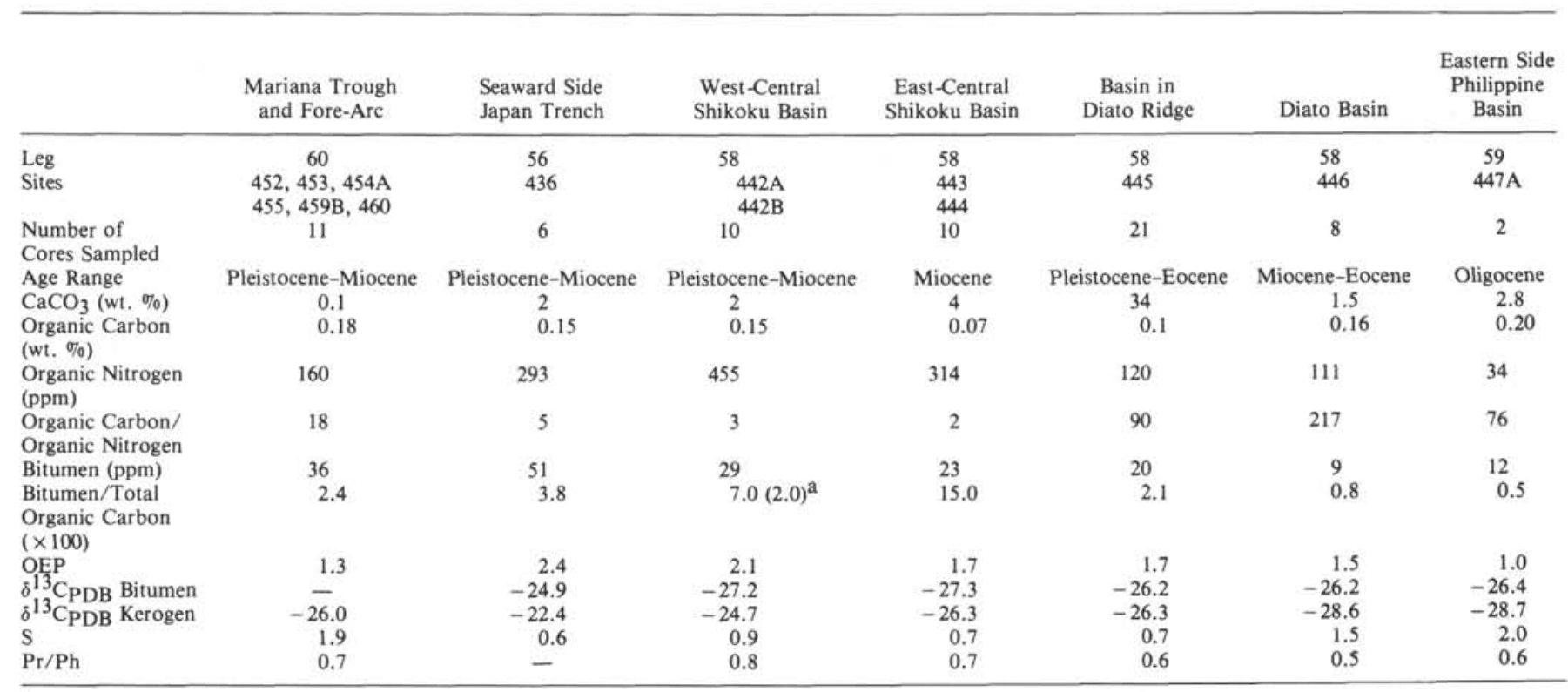

${ }^{a}$ Number in parenthesis is the average of those samples less than $10 \%$.

\begin{tabular}{|c|c|c|c|c|c|c|}
\hline & $\begin{array}{l}\text { Western Edge } \\
\text { Kyushu-Palau } \\
\text { Ridge }\end{array}$ & $\begin{array}{l}\text { Western Side } \\
\text { Parece-Vela } \\
\text { Basin }\end{array}$ & $\begin{array}{c}\text { Eastern Side } \\
\text { Parece-Vela } \\
\text { Basin }\end{array}$ & $\begin{array}{c}\text { Eastern Edge } \\
\text { West Mariana } \\
\text { Ridge }\end{array}$ & Nauru Basin & $\begin{array}{c}\text { Average Value } \\
\text { for All but } \\
\text { Nauru Basin } \\
\text { Sediments }\end{array}$ \\
\hline Leg & 59 & 59 & 59 & 59 & 61 & - \\
\hline Sites & 448 & 449 & 450 & 451 & 462 & - \\
\hline $\begin{array}{l}\text { Number of } \\
\text { Cores Sampled }\end{array}$ & 4 & 3 & 7 & 3 & 8 & - \\
\hline Age Range & Miocene-Oligocene & Miocene & Pliocene-Miocene & Pleistocene-Miocene & Pleistocene-Cenomanian & - \\
\hline $\mathrm{CaCO}_{3}$ (wt. \%) & 75 & 21 & 11 & 11 & 54 & 14.6 \\
\hline $\begin{array}{l}\text { Organic Carbon } \\
(w t . \%)\end{array}$ & 0.12 & 0.18 & 0.12 & 0.14 & 0.09 & 0.14 \\
\hline $\begin{array}{l}\text { Organic Nitrogen } \\
\text { (ppm) }\end{array}$ & 28 & 43 & 38 & 110 & 140 & 155 \\
\hline $\begin{array}{l}\text { Organic Carbon/ } \\
\text { Organic Nitrogen }\end{array}$ & 36 & 52 & 35 & 29 & 9 & 57 \\
\hline Bitumen (ppm) & 12 & 3 & $77(14)^{\mathrm{a}}$ & 10 & 8 & 26 \\
\hline $\begin{array}{l}\text { Bitumen/Total } \\
\text { Organic Carbon } \\
(\times 100)\end{array}$ & 1.1 & 0.7 & 4.9 & 0.9 & 1.5 & 3.6 \\
\hline OEP & 1.4 & 1.3 & 1.5 & 1.5 & 1.3 & 1.6 \\
\hline$\delta^{13} \mathrm{C}_{\mathrm{PDB}}$ Bitumen & -25.9 & -28.4 & -27.0 & - & - & -26.6 \\
\hline$\delta^{13} \mathrm{CPDB}_{\mathrm{PD}}$ Kerogen & -27.1 & -27.1 & -28.1 & -27.6 & - & -26.6 \\
\hline $\mathrm{S}$ & 1.2 & 1.3 & 1.4 & 1.2 & 1.2 & 1.2 \\
\hline $\mathrm{Pr} / \mathrm{Ph}$ & 0.7 & 0.4 & 0.5 & 0.5 & 0.5 & 0.6 \\
\hline
\end{tabular}

